\title{
HUBUNGAN TINGKAT PENGETAHUAN DENGAN KEPATUHAN TENAGA KESEHATAN TERHADAP PERATURAN PEMERINTAH NO.33 TAHUN 2012 TENTANG PEMBERIAN ASI EKSKLUSIF
}

\author{
RELATIONSHIP BETWEEN KNOWLEDGE AND HEALTH WORKER \\ COMPLIANCE TO GOVERNMENT REGULATION NO.33 OF 2012 \\ CONCERNING EXCLUSIVE ASSUMPTION
}

\author{
Friska Realita \\ Program studi D3 Kebidanan, Fakultas Kedokteran, \\ Universitas Islam Sultan Agung Semarang \\ Email : friskarealita@unissula.ac.id
}

\begin{abstract}
ABSTRAK
Salah satu proses alamiah adalah menyusi, berjuta ibu- ibu di seluruh dunia berhasil menyusui bayinya tanpa membaca buku tentang Air Susu Ibu (ASI). Bahkan ibu yang buta huruf dapat menyusui anaknya dengan sempurna. Untuk keberhasilan menyusui tidak diperlukan alat-alat khusus dan biaya yang mahal. Yang diperlukan hanyalah kesabaran, waktu, sedikit tentang pengetahuan tentang menyusui, dan dukungan dari lingkungan terutama suami. Sudah dijelaskan diPasal 17 ayat (1) PP No. 33 Tahun 2012 tentang Pemberian ASI Eksklusif, Susu Formula dilarang diberikan oleh Tenaga Kesehatan atau produk bayi lainnya yang dapat menghambat program pemberian ASI Eksklusif. Variabel independen dari penelitian ini adalah PP 33 Tahun 2012 tentang asi eksklusif, Variabel dependent dari penelitian ini adalah Tenaga Kesehatan yang berhubungan dengan Ruang ibu Melahirkan seperti perawat dan Bidan di Rumah Sakit Islam Sultan Agung Semarang. Penelitian ini menggunakan metode belah lintang (cross sectional) dimana seluruh variabel yang terdiri dari variabel independent dan variabel dependent, populasi pada peneltian ini Tenaga Kesehatan yang berhubungan dengan Ibu Melahirkan di Rumah Sakit Islam Sultan Agung Semarang, teknik dalam penelitian yaitu non probability sampling yaitu sampling jenuhsebanyak 30 sampel. . Hasil Penelitian responden yang memiliki tingkat pengetahuan yang cukup baik dengan memiliki proporsi yang paling besar yaitu sebanyak 56,67\% sedangkan yang memiliki pengetahuan yang baik hanya sebanyak 30,00\%. Jumlah responden yang memiliki kepatuhan memiliki proporsi sebesar 93,33\%. Hasil penelitian mendapatkan bahwa ada hubungan positif yang signifikan antara pengetahuan mengenai PP 33 dengan kepatuhan terhadap PP 33 tersebut dengan tingkat hubungan yang cukup kuat. Hasil ini menunjukkan bahwa pengetahuan yang baik akan menjadikan mereka memiliki kepatuhan yang lebih besar terhadap PP 33.
\end{abstract}

Kata kunci :Kepatuhan, tenaga kesehatan, PP 33, Asi Eksklusif

\begin{abstract}
Breastfeeding is a natural process, millions of mothers around the world have managed to breastfeed their babies without ever reading a book about breast milk (ASI). Even mothers who are illiterate can breastfeed their children well. For successful breastfeeding special tools and expensive costs are not needed. All that is needed is patience, time, a little about knowledge about breastfeeding, and support from the environment, especially husband. It has been explained in Article 17 paragraph (1) PP No. 33 of 2012 concerning the Exclusive Provision of Mother's Milk, every health worker is prohibited from providing infant formula milk and / or other baby products that can hinder the Exclusive breastfeeding program except in the case of intended purpose. To find out the Compliance of Health
\end{abstract}


Workers Against Government Regulation No.33 of 2012 concerning Exclusive Provision of Breastfeeding at Sultan Agung Islamic Hospital, Semarang. The independent variables of this study are PP 33 of 2012 concerning exclusive breastfeeding, the dependent variables of this study are Health Workers who are associated with Childbirth Mother Room such as nurses and Midwives in Sultan Agung Islamic Hospital Semarang. This study uses cross sectional method where all variables consist of independent variables and dependent variables, the population in this study Health Workers related to Mother Gives Birth in Sultan Agung Islamic Hospital Semarang, In this study using nonprobability sampling technique that is saturated sampling of 30 samples. . Research Results respondents who have a fairly good level of knowledge by having the largest proportion of as much as $56.67 \%$ while those who have good knowledge only as much as 30.00\%. The number of respondents who have compliance has a proportion of $93.33 \%$. The results showed that there was a significant positive relationship between knowledge about PP 33 and compliance with PP 33 with a fairly strong level of relationship. These results indicate that good knowledge will make them have greater compliance with PP 33.

Keywords : Compliance, health personnel, PP 33, Exclusive Asi 


\section{PENDAHULUAN}

Salah satu proses alamiah adalah menyusi, berjuta ibu- ibu di seluruh dunia berhasil menyusui bayinya tanpa membaca buku tentang Air Susu Ibu (ASI). Bahkan ibu yang buta huruf dapat menyusui anaknya dengan sempurna . kesabaran dan waktu sangat diperlukan dalam ASI Eksklusif , pengetahuan tentang ASI ekslusif, dan dukungan lingkungan terutama suami (Roesli,2009).

Menyusui eksklusif adalah bayi hanya diberikan ASI tanpa tambahan cairan lain atau makanan padat. bayi hanya di beri ASI saja secara eksklusif sejak lahir selama 6 bulan (Roesli, 2008;H.2). diteruskan sampai 2 tahun. pemberian ASI secara eksklusif mencegah kematian balita sebanyak 13\%, sedangkan pemberian ASI eksklusif selama 6 bulan dilanjutkan dengan pemberian ASI sampai lebih dari 2 tahun yang tepat dapat mencegah kematian balita sebanyak $19 \%$ bersama makanan pendamping ASI (Suradi dan Roesli).

Cakupan pemberian ASI setingkat nasional di Indonesia selam tiga tahun terakhir yaitu sampai 6 bulan turun dari $28,6 \%$ pada tahun 2007 menjadi $24,3 \%$ pada tahun 2008 dan naik lagi menjadi 34,3\% pada tahun 2009 (Profil Kesehatan RI,2010).

Praktik Pelayanan Kesehatan dapat berpengaruh besar terhadap menyusui, Praktik yang buruk mengganggu menyusui dan berkontribusi terhadap penyebaran pemberian susu formula. ( UNICEF, 2011) Pada Peraturan Pemerintah Republik Indonesia No 33 tentang Pemberian ASI Esklusif dijelaskan untuk mencapai pemanfaatan pemberian maksimal ASI eksklusif , Bidan, Tenaga Kesehatan juga Institusi kesehatan wajib selalu memberikan informai dan Pendidikan ASI Eksklusif kepada ibu dan anggota keluarga dari janin sampai bayi lahir dan sampai ASI ekslusif slesai selama 6 bulan dilanjutkan dengan ASI dan MP ASI selama 2 tahun..

Sesuai PP no 33 Tahun 2012 tersebut, sejak lahir sampai usia 6 bulan seharusnya bayi mendapatkan ASI
Eksklusif, bukan diberikan susu formula. Namun sekarang ini banyak ibu yang tidak memberikan ASI eksklusif kepada bayinya waktu, pendidikan / pengetahuan, pengiklanan susu formula, dan lain-lain.

Banyak faktor yang menyebabkan menghambatnya pemberian ASI yaitu Faktor pengiklanan di media cetak, masa dan media online. Ha ini menyebabkan iklan - iklan susu formula tersebut mengakibatkan ibu lebih nyaman memberikan susu formula dibandingkan dengan ASI Eksklusif. Padahal komposisi ASI Eksklusif dari pada susu formula jauh lebih baik .

Parahnya lagi banyak ditemukan iklan , promosi susu formula dapat ditemukan di fasilitas pelayanan kesehatan seperti puskesmas, Rumah Sakit, Klinik Kesehatan dalam bentuk kalender, jam dinding, pengukur tinggi badan, poster dan lain-lain.

Tenaga medis ada yang ditemukan menawarkan susu formula pada ibu setelagh lahir, karena 1-2 hari bayi lahir banyak ASI yang tidak keluar dan Ibu takut anaknya tidak mendapatkan gizi. Padalah menurut PP promosi susu formula di fasilitas pelayanan kesehatan dan oleh tenaga kesehatan tidak diperbolehkan dan sudah diatur dalam peraturan.

Hal ini dijelaskan diPasal PP No. 33 Tahun 2012 tentang Pemberian ASI Eksklusif 17 ayat (1) , Susu Formula dilarang diberikan oleh Tenaga Kesehatan atau produk bayi lainnya yang dapat menghambat program pemberian ASI Eksklusif .

Sedangkan untuk fasilitas pelayanan kesehatannya dijelaskan dalam PP No. 33 Tahun 2012 tentang Pemberian Air Susu Ibu Eksklusif Pasal 18 ayat (1) , penyelenggara fasilitas pelayanan kesehatan dilarang memberikan susu formula bayi dan/atau produk bayi lainnya yang dapat menghambat program pemberian ASI Eksklusif kepada ibu bayi dan/atau keluarganya, kecuali dalam hal diperuntukkan sebagaimana dimaksud dalam Pasal 15. 
Hal yang sudah dijelaskan diatas sudah sangat terlihat bahwa di PP yang sudah diatur masih banyak yang melanggar yaitu tenaga kesehatan yang menawarkan pada ibu setelah melahirkan sampai pihak susu formula mengiming - imingi reward pada tenaga kesehatan.

Dalam PP No. 33 Tahun 2012 Pasal 18 ayat (2) tentang Pemberian Air Susu Ibu Eksklusif pun dijelaskan bahwa, penyelenggara fasilitas pelayanan kesehatan tidak diperbolehkan menerima dan/atau mempromosikan susu formula bayi dan/atau produk bayi lainnya yang dapat menghambat program pemberian ASI Eksklusif.

Apabila ada tenaga kesehatan melanggar peraturan tersebut maka akan dikenakan PP No. 33 Tahun 2012 Pasal 29 ayat (1) tentang Pemberian Air Susu Ibu Eksklusif, setiap tenaga kesehatan yang tidak melaksanakan ketentuan sebagaimana dimaksud dalam Pasal 16, Pasal 17, Pasal 21 ayat (1), dan Pasal 23 ayat (1), dikenakan sanksi administratif oleh pejabat yang berwenang berupa: teguran lisan; teguran tertulis; dan/atau pencabutan izin. Mayoritas menggantinya dengan susu formula bayi. Hal ini dikarenakan oleh faktor pekerjaan.

\section{METODE PENELITIAN}

Variabel independen dari penelitian ini adalah PP 33 Tahun 2012 tentang asi eksklusif. Variabel dependent penelitian ini yaitu Tenaga Kesehatan yang berhubungan dengan Ruang ibu Melahirkan seperti perawat dan Bidan di Rumah Sakit Islam Sultan Agung Semarang.

Jenis penelitian yang digunakan adalah penelitian observasional yang bersifat analitik. Penelitian observasional yaitu penelitian yang tidak memberikan perlakuan pada subyek penelitian.

Penelitian yang bersifat analitik merupakan penelitian yang bertujuan mencari keterkaitan variabel satu dengan variabel yang lainnya. Desain penelitian ini menggunakan desain belah lintang (cross sectional) dimana seluruh variabel yang terdiri dari variabel independent dan variabel dependent diukur pada waktu yang sama yaitu pada saat penelitian berlangsung, yang dilaksanakan dengan wawancara menggunakan kuesioner.

Populasi dalam penelitian ini adalah Tenaga Kesehatan yang berhubungan dengan Ibu Melahirkan di Rumah Sakit Islam Sultan Agung Semarang. Sampel dalam penelitian ini adalah Tenaga Kesehatan yang berhubungan dengan Ibu Melahirkan di Rumah Sakit Islam Sultan Agung Semarang sebanyak 30 Tenaga Kesehatan. Pada penelitian ini menggunakan teknik non probability sampling yaitu sampling jenuh. Sampling jenuh yaitu penentuan teknik sampel bila anggota populasi digunakan sebagai sampel (Sugiyono, 2007). Jadi, jumlah sampel dalam penelitian ini sebanyak 30 sampel. Penelitian ini menggunakan form penilaian yang telah dibuat sebelumnya. Data Analisis meliputi statistik deskriptif dan uji hipotesis. Pada statistik deskriptif, data yang berskala nominal dinyatakan sebagai persentase. Uji hipotesis menggunakan uji chi-square dikarenakan data yang diambil memiliki skala yang berbeda. Analisis data dilakukan dengan program komputer.

\section{HASIL DAN PEMBAHASAN}

Distribusi Frekuensi Penilaian mengenai Pengetahuan Mengenai PP 33

Pengukuran mengenai pengetahuan mengenai PP 33 diukur berdasarkan 11 item kuesioner yang dijawab oleh responden. Pengetahuan mengenai PP No. 33 Tahun 2012 tentang Pemberian Air Susu Ibu Eksklusif mengijinkan adanya iklan susu formula bayi di fasilitas pelayanan kesehatan masyarakat dan PP No. 33 Tahun 2012 Tentang Pemberian Air Susu Ibu Eksklusif, apakah pemasangan iklan susu formula bayi boleh dilakukan di Rumah Sakit diketahui oleh seluruh responden, sedangkan pengetahuan mengenai fasilitas pelayanan 
kesehatan masyarakat yang diijinkan untukmemasang iklan susu formula bayi diketahui oleh paling sedikit responden,

Hasil penilaian mengenai pengetahuan ibu selanjutnya dikategorikan ke dalam 3 kategori : kurang, cukup dan baik. Berdasarkan tingkat pengetahuan mengenai PP 33 diperoleh hasil sebagai berikut :

Tabel 1.Distribusi Kategori Pengetahuan PP 33

\begin{tabular}{lll}
\hline \multirow{2}{*}{$\begin{array}{l}\text { Pengetahuan menge } \\
\text { PP 33 }\end{array}$} & \multicolumn{2}{l}{ Distribusi frekuensi } \\
\cline { 2 - 3 } & Jumlah & Persentase \\
\hline Kurang & 4 & 13,33 \\
& 17 & 56,67 \\
Cukup & 9 & 30,00 \\
Baik & 30 & 100,00 \\
\hline Total &
\end{tabular}

Berdasarkan tabel 1 menunjukkan bahwa jumlah responden yang memiliki tingkat pengetahuan yang cukup baikadalah yang paling banyak yaitu sebanyak 17 orang atau 50,67\%. Responden dengan pengetahuan yang baik menempati urutan kedua yaitu sebanyak 9 orang atau $30,00 \%$ dan yang paling sedikit adalah responden yang memiliki pengetahuan kurang yaitu sebanyak 4 orang atau $10,33 \%$.

Hasil penelitian mendapatkan bahwa responden yang memiliki tingkat pengetahuan yang cukup baik dengan memiliki proporsi yang paling besar yaitu sebanyak $56,67 \%$ sedangkan yang memiliki pengetahuan yang baik hanya sebanyak 30,00\%. Hasil ini menceminkan bahwa bidan dan perawat di RSI Sultan Agung Semarang sudah cukup memahami mengenai isi yang terkandung dalam PP 33.

Berdasarkan hasil jawaban menunjukkan bahwa cukup banyak responden yang menyatakan mengetahui inti dari Peraturan Pemerintah No 33 tersebut.Pada PP No. 13 tahun 2012 khususnya pada pasal 17 berisi mengenai larangan bagi tenaga kesehatan untuk memberikan dan mempromosikan susu formula. Pengetahuan bidan dan perawat mengenai hal tersebut sekiranya menjadi hal yang penting.

Kondisi pengetahuan mengenai PP 33 yang relative baik dapat diperoleh karena adanya tingkat pendidikan yang dimiliki sampel yang terkait langsung dengan bidang kesehatan.Sampel penelitian adalah bidan dan perawat yang memang seharusnya memiliki pendidikan yang relative tinggi. Kondisi demikian menjadikan pemahaman akanPP 33 relatif tinggi.

Diperolehnya tingkat pengetahuan sampel yang relative tinggi ini sesuai dengan pendapat Notoadmojo (2003) bahwa tingkat pengetahuan dapat dipengaruhi oleh karakteristik seperti pengalaman, dan pendidikan.Responden dengan pendidikan tinggi akan menciptakan pengetahuan yang relatif baik.

Sebaliknya adanya pendidikan yang relative kurang baik pada sebagian responden, menjadikan penerimaan responden terhadap berbagai informasi mengenai PP 33kurang diterima oleh beberapa sampel penelitian. Dalam pendidikan formal yang tinggi,

Pengetahuan mengenai PP 33 selain didapatkan dari pendidikan formal, juga dapat diperoleh dari adanya ketettuan profesi di lokasi kerja maupun dari informasi dari media seperti televisi, radio maupun media cetak.Dewasa ini dengan perkembangan teknologi informasi, berbagai macam informasi dapat diakses dengan mudah oleh banyak kalangan.

Tabel 6.Distribusi Frekuensi Responden Menurut Kepatuhan

\begin{tabular}{lll}
\hline Kepatuhan & \multicolumn{2}{l}{ Distribusi frekuensi } \\
\cline { 2 - 3 } & Jumlah & Persentase \\
& & \\
\hline Tidak patuh & 2 & 6,67 \\
Patuh & 28 & 93,33 \\
\hline Total & 30 & 100,00 \\
\hline
\end{tabular}

Berdasarkan tabel 4 menunjukkan bahwa jumlah responden yang memiliki 
tingkat kepatihan yang baik memiliki proporsi yang paling banyak yaitu sebanyak 28 orang atau $93,67 \%$ dan responden yang tidak patuh sebanyak 2 orang atau $6,67 \%$.

Hasil penelitian mendapatkan bahwa responden yang memiliki tingkat kepatuhan yang cukup baik yang lebih banyak dibanding yang tidak patuh. Jumlah responden yang memiliki kepatuhan memiliki proporsi sebesar 93,33\%.

Kepatuhan adalah salah satu perilaku seseorang untuk bertindak patuh terhadap peraturan. Kepatuhan merupakan kesetiaan, ketaatan atau loyalitas. Menurut Smet, kepatuhan adalah tingkat seseorang melaksanakan suatu cara atau berperilaku sesuai dengan apa yang disarankan atau dibebankan kepadanya.

Banyaknya responden yang memiliki kepatuhan yang besar terhadap PP 33 dapat terkait dengan kemauan dan kesadaran mereka yang sudah mengerti akan arti pentingnya ASI ekslusif bagi bayi. Selaitu itu aspek pembatasan iklan susu formula menjadikan banyak responden yang termotivasi untuk patuh terhadap PP 33 tersebut.

Responden nampaknya sudah mamiliki sikap untuk patuh terhadap PP 33 tersebut.Selain itu responden juga dimungkinkan menerima pengar\$ahan mengenai PP 33 tersebut dari Dinas Kesehatan.Adanya pemberian peringatan dari pihak terkait untuk mematuhi PP 33 menjadikan cukup banyak bidan dan perawat untuk aktif dalam mematuhi PP 33.Peringatan dari pihak pemerintah nampaknya menjadi pendorong untuk termotivasi dalam mematuhi peratuan tersebut.Meskpun demikian, adanya beberapa responden yang memiliki kepatuhan yang rendah dapat dikarenakan mereka kurang mengerti mengenai sanksi yang menyertai PP terseb ut.

Hasil penelitian mendapatkan bahwa ada hubungan positif yang signifikan antara pengetahuan mengenai PP 33 dengan kepatuhan terhadap PP 33 tersebut dengan tingkat hubungan yang cukup kuat. Hasil ini menunjukkan bahwa pengetahuan yang baik akan menjadikan mereka memiliki kepatuhan yang lebih besar terhadap PP 33.

Hasil ini menunjukkan bahwa dorongan atau keinginan untuk mematuhi PP 33 tidak lepas dari pengetahuan yang dimiliki oleh masing-masing individu. Peran pengetahuan nampaknya dapat menjadi sumber pengingat mengenai pemahaman akanarti pentinhnya PP 33 tersebut untuk kesehatan masyarakat.

Kesadaran para bidan dan perawat untuk mematuhi PP 33 tersebut juga didasarkan pada tidak inginnya para ibu mendapatkan masalah kesehatan bagi para bayi mereka pada masa yang akan datang. Penhgetahuan memberikan gambaran akan kondisi yang dapat terjadi apabila tidak melakukan kepatuhan terhadap PP 33 tersebut secara umum.

Tingkat pengetahuan maupun informasi yang sudah diterima menjadikan mereka mengenai arti pentingnya ASI ekslusif.Bagi bidan dan perawat yang sudah memiliki pengetahuan akan kondisi demikian nampaknya dapat mendorong diri mereka untuk mau mematuhi peraturan dalam PP 33 tersebut.

Pengetahuan individu bidan dan perawat nampaknya menjadi hal yang penting dalam penerapan PP 33 tersebut, mengingat adanya kenaikan kasus kurangnya kesadaran ib $\mathrm{u}-\mathrm{i}$ bu untuk memberikan ASI ekslusif kepada bayi mereka karena sudah banyaknya susu formula yang dijual di pasar. Selain itu setiap diri individu bidan dan perawat juga mempunyai peran yang besar di dalam mencegah terjadinya kurangnya pemberian ASI ekslusif.Implementasi dari Pada PP No. 13 tahun 2012 oleh bidan dan perawat menjadi salah satu tolok ukur dari efektivitas PP tersebut. Jadi Penerapan dari bidan atas pelaksanaan PP tersebut menjadi hal yang penting.

Berdasarkan hasil jawaban responden menunjukkan bahwa semua responden menyatakan bahwa mereka sudah 
banyakmenerapkan PP tersebut, meskipunsebagian kecil responden menyatakan bahwa mereka masih memegang kontrak dengan produsen susu formula. Namun demikian dalam kontrak mereka mereka menyebutkan hanya untuk susu di atas 6 bulan.

Keberadaan PP No. 33 tahun 2012 tersebut setidaknya memberikan batasan terhadap sesuatu yang seharusnya tidak boleh dilakukan oleh bidan.Sebelum dikeluarkannya PP No. 33 tahun 2012, promosi susu formula untuk bayi usia 0 6 bulan baik promosi langsung melalui enaga penjual yang melibatkan bidan atau dokter nampaknya masih menjadi hal yang biasa. Keberadaan pengetahuan dan pemahaman mengenai PP 33 dengan beserta sanksi yang ada nampaknya dapat menajdikan kepatuhan menjadi lebih baik.

\section{SIMPULAN}

Berdasarkan hasil penelitian dan pembahasan yang telah dipaparkan pada bab terdahulu, maka dapat disimpulkan sebagai berikut : Sebagian besar responden maih memiliki pengetahuan yang sudah cukup baik.Sebagian besar responden memiliki perilaku kepatuhan yang baik terhadap pelaksanaan PP 33 . Hasil analisis menunjukkan bahwa ada hubungan positif antara pengetahuan dengan kepatuhan pelaksanaan PP 33 dengan hubungan yang cukup kuat.

\section{DAFTAR PUSTAKA}

Peraturan Pemerintah Republik Indonesia Nomor 33 Tahun 2012 Tentang Pemberian Air Susu Ibu Eksklusif.

Sukmawati, Diana. Hubungan frekuensi paparan iklan susu formula terhadap ibu dengan praktik pemberian ASI di RW 02 Kelurahan Waru, Kecamatan Parung, Kabupaten Bogor. Jakarta: Universitas Pembangunan Nasional Veteran; 2012.

Sjarif DR, Lestari ED, Mexitalia M, Nasar SS. Buku Ajar Nutrisi Pediatrik Dan
Penyakit Metabolik Jilid 1. Jakarta: Badan Penerbit IDAI; 2011.

PMK (Peraturan Menteri Kesehatan) No.

6 tahun 2013 tentang Kriteria Fasilitas Pelayanan Kesehatan.

PMK No. 71 tahun 2013 tentang Pelayanan Kesehatan Pada Jaminan Kesehatan Nasional.

Keputusan Menteri Kesehatan Republik Indonesia Nomor 128/Menkes/SK/II/2004.

Lisa A, Hartadi P, Luciana, Yuzie Q, Husnul K, Sismiyati, dkk. Laporan Praktek Kerja Lapangan Dan Pengembangan Desa Siaga Di Desa Semambung Kecamatan Gedangan Kabupaten Sidoarjo. Surabaya: Universitas Wijaya Kusuma; 2008.

Visyara, Novina Ika. Beberapa Faktor Yang Berhubungan Dengan Pemberian MP ASI Pada Bayi Usia 0-6 Bulan Di BPS Heni Suharni Desa Langensari Kecamatan Ungaran Barat Kabupaten Semarang. Ungaran: Akademi Kebidanan Ngudi Waluyo; 2012.

Pungkas BA, Dadang RA, Sularsono. Kajian Kebijakan Perencanaan

Tenaga Kesehatan. Jakarta:

Direktorat Kesehatan Dan Gizi Masyarakat Kementerian Perencanaan Pembangunan Nasional; 2005.

Marwiyah, Ida. Hubungan Antara Pemberian Susu Formula Sebagai PASI Dengan Status Gizi Pada Bayi Usia 0-6 Bulan (Studi Kasus di BPS Hj. Isna Abdi Pabean-Sidoarjo). Surabaya: Sekolah Tinggi Ilmu Kesehatan "Artha Bodhi Iswara"; 2007.

Wahyudi, S. Tanggung Jawab Rumah Sakit Terhadap Kerugian Akibat Kelalaian Tenaga Kesehatan Dan Implikasinya. Purwokerto: Universitas Jenderal Soedirman; 2011. 